\title{
Role of $\mathrm{VIP}_{1} /$ PACAP receptors in postoperative ileus in rats
}

\author{
${ }^{1}$ Benedicte Y. De Winter, ${ }^{2}$ Patrick Robberecht, ${ }^{3}$ Guy E. Boeckxstaens, ${ }^{1}$ Joris G. De Man, \\ ${ }^{1}$ Tom G. Moreels, ${ }^{1}$ Arnold G. Herman \& ${ }^{1,4}$ Paul A. Pelckmans
}

${ }^{1}$ Division of Gastroenterology and Pharmacology, Faculty of Medicine, University of Antwerp, Universiteitsplein 1, 2610 Antwerp, Belgium; ${ }^{2}$ Department of Biochemistry and Nutrition, Medical School, Université Libre de Bruxelles, Route de Lennik 808 , 1070 Brussels, Belgium and ${ }^{3}$ Division of Gastroenterology and Hepatology, Academic Medical Centre, Meibergdreef 9, 1105 AZ Amsterdam, The Netherlands

1 Vasoactive intestinal polypeptide (VIP) is an inhibitory neurotransmitter in the enteric nervous system. We investigated the role of $\mathrm{VIP}_{1} / \mathrm{PACAP}$ receptors in postoperative ileus in rats.

2 Different degrees of inhibition of the gastrointestinal transit, measured by the migration of Evans blue, were achieved by skin incision, laparotomy or laparotomy plus mechanical stimulation of the gut. 3 The transit after skin incision or laparotomy was not altered by the $\mathrm{VIP}_{1} / \mathrm{PACAP}$ receptor antagonist Ac-Hisl,D-Phe ${ }^{2}, \mathrm{~K}^{15}, \mathrm{R}^{16}$, VIP(3-7), GRF(8-27)- $\mathrm{NH}_{2}$ nor by the $\mathrm{VIP}_{1} / \mathrm{PACAP}$ receptor agonist $\mathrm{K}^{15}$, $\mathrm{R}^{16}$, VIP(1-7), GRF(8-27)- $\mathrm{NH}_{2}$ and the $\mathrm{VIP}_{2} / \mathrm{PACAP}$ receptor agonist $\mathrm{RO} 25-1553\left(5 \mu \mathrm{g} \mathrm{kg}^{-1}\right)$.

4 However, the transit after laparotomy plus mechanical stimulation was significantly enhanced by the $\mathrm{VIP}_{1} /$ PACAP receptor antagonist, whereas it was further inhibited by the VIP $/$ PACAP receptor agonist. The combination of the $\mathrm{VIP}_{1} / \mathrm{PACAP}$ receptor agonist and antagonist counteracted the effect of both drugs alone. The $\mathrm{VIP}_{2} / \mathrm{PACAP}$ receptor agonist did not alter the effect of the $\mathrm{VIP}_{1} / \mathrm{PACAP}$ receptor antagonist.

5 The combination of the $\mathrm{VIP}_{1} / \mathrm{PACAP}$ receptor antagonist plus the nitric oxide (NO) synthase inhibitor L-nitroarginine had no effect on the transit after laparotomy plus mechanical stimulation, while the transit after skin incision was significantly decreased.

6 These findings suggest the involvement of $\mathrm{VIP}_{1} / \mathrm{PACAP}$ receptors, next to NO, in the pathogenesis of postoperative ileus. However, the combination of the VIP $/$ PACAP antagonist and the NO synthase inhibitor abolished the beneficial effect of each drug alone, suggesting the need for one of the inhibitory neurotransmitters to enable normal gastrointestinal transit.

Keywords: Nitric oxide; vasoactive intestinal polypeptide; transit; ileus; $\mathrm{VIP}_{1}$ receptor; $\mathrm{VIP}_{2}$ receptor

\section{Introduction}

It is generally accepted that postoperative ileus involves the activation of an inhibitory reflex pathway with the efferent limb consisting of adrenergic fibres and the afferent limb consisting of capsaicin sensitive fibres (Dubois et al., 1973; Furness \& Costa, 1974; Holzer et al., 1986; Livingston \& Passaro, 1990). However, other mechanisms such as the activation of non-adrenergic non-cholinergic (NANC) nerves may contribute as well (Abrahamsson et al., 1979). We previously showed that mechanical stimulation of the small intestine and caecum triggers an additional non-adrenergic pathway mediated by nitric oxide (NO). Blockade of NO synthase by the arginine analogue L-nitroarginine completely reversed the additional inhibition of the transit induced by mechanical stimulation of the gut (De Winter et al., 1997). On the other hand, several authors suggest an involvement of vasoactive intestinal polypeptide (VIP) in the pathophysiology of small bowel obstruction and postoperative ileus (Basson et al., 1989; Espat et al., 1995). Espat et al. (1995) reported an improvement in postoperative small bowel transit in the rat after treatment with a non-selective VIP receptor antagonist, (D-p-Cl-Phe ${ }^{6}, \mathrm{Leu}^{17}$ ) VIP.

VIP and NO are both postulated as inhibitory neurotransmitters of the enteric nervous system (Goyal et al., 1980; Grider \& Rivier, 1990; Boeckxstaens et al., 1991; Furness et al., 1992; Goyal \& Hirano, 1996). Co-localisation of VIP and NO was demonstrated in the enteric neurons of the guinea

\footnotetext{
${ }^{4}$ Author for correspondence.
}

pig, opossum and rat gastrointestinal tract (Costa et al., 1992; Ekblad et al., 1994; Lynn et al., 1995). The VIP receptors are a subclass of PACAP (pituitary adenylate cyclase activating peptide) type II receptors. The PACAP type I receptors have greater affinity for PACAP than for VIP, while the PACAP type II receptors are equally activated by PACAP and VIP (Usdin et al., 1994; Shuttleworth \& Keef, 1995). Recently the $\mathrm{VIP}_{1} / \mathrm{PACAP}\left(\mathrm{VIP}_{1}\right)$ and $\mathrm{VIP}_{2} / \mathrm{PACAP}\left(\mathrm{VIP}_{2}\right)$ receptors were cloned with different distributions in the rat. The $\mathrm{VIP}_{2}$ receptor mRNA was most abundant in the stomach, whereas the $\mathrm{VIP}_{1}$ receptor mRNA was mostly present in the small intestine (Usdin et al., 1994). Subsequently, $\mathrm{VIP}_{1}$ and $\mathrm{VIP}_{2}$ receptor agonists and antagonists were developed. Ac-Hisl,D$\mathrm{Phe}^{2}, \mathrm{~K}^{15}, \mathrm{R}^{16}, \mathrm{VIP}(3-7), \mathrm{GRF}(8-27)-\mathrm{NH}_{2}$, a high affinity selective antagonist of the $\mathrm{VIP}_{1}$ receptor was synthesised and shown to be selective for the rat $\mathrm{VIP}_{1}$ receptor in vitro (Gourlet et al., 1997a). This $\mathrm{VIP}_{1}$ receptor antagonist was synthesised by analogy with the selective $\mathrm{VIP}_{1}$ receptor agonist derived from growth hormone releasing factor (GRF): $\mathrm{K}^{15}, \mathrm{R}^{16}, \mathrm{VIP}(1-7), \mathrm{GRF}(8-27)-\mathrm{NH}_{2}$ (Gourlet et al., 1997b). RO 25-1553 was proven to be a highly selective $\mathrm{VIP}_{2}$ receptor agonist in vitro (Gourlet et al., 1997c). Actually, there is no high affinity $\mathrm{VIP}_{2}$ receptor antagonist available. Therefore, in the present study we investigated the effect of the selective $\mathrm{VIP}_{1}$ receptor agonist and antagonist and the $\mathrm{VIP}_{2}$ receptor agonist in our rat model of postoperative ileus. As we previously demonstrated the involvement of $\mathrm{NO}$ in the pathogenesis of postoperative ileus we also investigated the interaction between NO and VIP. 


\section{Methods}

\section{Operation protocol}

All procedures received approval from the Medical Ethical Committee of the University of Antwerp (U.I.A.). Male Wistar rats $(150-240 \mathrm{~g})$ were fasted for $48 \mathrm{~h}$ with free access to water. The operation protocol was previously described in detail (De Winter et al., 1997). Briefly, the rats were divided in three groups in a randomised way and underwent an abdominal operation under ether anaesthesia. Ether anaesthesia was chosen as, in contrast to pentobarbital, its effects on gastrointestinal motility were shown to last for only $1 \mathrm{~h}$ after the induction of the anaesthesia (Bueno et al., 1978; De Winter et al., 1997). The first group underwent an abdominal skin incision (SI) after shaving and disinfecting the abdomen. The second group underwent a laparotomy (LAP) consisting of the incision of the abdominal skin, the abdominal muscle layers and the peritoneum. The third group underwent a laparotomy followed by the evisceration and mechanical stimulation of the small intestine and caecum $(\mathrm{L}+\mathrm{M})$. Therefore, the small intestine and caecum were gently pulled out of the abdominal cavity and unfurled like a fan on two sterile gauzes covering the abdomen of the rat. Five minutes later the intestines were replaced in the abdominal cavity and the surgical wound was sutured. After the operation the rats were allowed to recover for $1 \mathrm{~h}$. Then they received an intragastric injection of $0.1 \mathrm{ml}$ Evans blue ( $50 \mathrm{mg}$ in $1 \mathrm{ml} 0.9 \%$ sodium chloride) (Tanila et al., 1993) via a specially designed orogastric cannula introduced through the mouth. Twenty minutes later the rats were killed by a cardiotomy under ether anaesthesia and the intestinal transit was measured from the pylorus to the most distal point of migration of Evans blue and expressed in $\mathrm{cm}$ migration.

\section{Experimental protocol}

In a first series of experiments we investigated the effect of different doses of the $\mathrm{VIP}_{1}$ receptor antagonist on the transit after the laparotomy plus mechanical stimulation. Therefore the rats were randomly divided in four groups before they underwent a laparotomy plus mechanical stimulation. The first group received an intravenous (i.v.) injection of $0.9 \%$ sodium chloride and served as control group. The second group was injected i.v. with the $\mathrm{VIP}_{1}$ receptor antagonist Ac-Hisl,D-Phe ${ }^{2}$, $\mathrm{K}^{15}, \mathrm{R}^{16}, \mathrm{VIP}(3-7), \operatorname{GRF}(8-27)-\mathrm{NH}_{2}$ in a dose of $3 \mu \mathrm{g} \mathrm{kg}^{-1}$ (Gourlet et al., 1997a). This concentration was similar to the concentration of the non-selective VIP receptor antagonist used by Espat et al. (1995). The third group received an i.v. injection of $5 \mu \mathrm{g} \mathrm{kg}^{-1} \mathrm{VIP}_{1}$ receptor antagonist and the fourth group received a dose of $10 \mu \mathrm{g} \mathrm{kg}^{-1} \mathrm{VIP}_{1}$ receptor antagonist $1 \mathrm{~min}$ before the laparotomy plus mechanical stimulation.

In a second series of experiments the effect of the VIP $_{1}$ receptor agonist and the $\mathrm{VIP}_{1}$ receptor antagonist was tested on the intestinal transit after the three different operations. The rats were randomly divided in four groups. The first group served as control group and received an i.v. injection of $0.9 \%$ sodium chloride in the tail vein. Then the rats underwent a skin incision, laparotomy or laparotomy plus mechanical stimulation. The second group received an i.v. injection of the $\mathrm{VIP}_{1}$ receptor antagonist Ac-Hisl,D-Phe ${ }^{2}, \mathrm{~K}^{15}, \mathrm{R}^{16}$, VIP(3-7), GRF $(8-27)-\mathrm{NH}_{2}\left(5 \mu \mathrm{g} \mathrm{kg}^{-1}\right) 1 \mathrm{~min}$ before the operation. The third group received an i.v. injection of the $\mathrm{VIP}_{1}$ receptor agonist $\mathrm{K}^{15}, \mathrm{R}^{16}, \operatorname{VIP}(1-7), \operatorname{GRF}(8-27)-\mathrm{NH}_{2}\left(5 \mu \mathrm{g} \mathrm{kg}^{-1}\right)$ 1 min before the operation (Gourlet et al., 1997b). The fourth group was injected i.v. with the $\mathrm{VIP}_{1}$ receptor antagonist immediately followed by an i.v. injection of the $\mathrm{VIP}_{1}$ receptor agonist $1 \mathrm{~min}$ before the operation.

In a third series of experiments we tested possible interaction of the $\mathrm{VIP}_{1}$ receptor antagonist with the $\mathrm{VIP}_{2}$ receptor. The rats were divided randomly in four groups. The first group served as control group and received an i.v. injection of $0.9 \%$ sodium chloride in the tail vein. Then they underwent a skin incision, laparotomy or laparotomy plus mechanical stimulation. The second group received an i.v. injection of the $\mathrm{VIP}_{1}$ receptor antagonist $\left(5 \mu \mathrm{g} \mathrm{kg}^{-1}\right) 1 \mathrm{~min}$ before the operation. The third group received an i.v. injection of RO 25-1553 $\left(5 \mu \mathrm{g} \mathrm{kg}^{-1}\right)$, a selective $\mathrm{VIP}_{2}$ receptor agonist (Gourlet et al., 1997c), 1 min before the operation. This dose was chosen in analogy with the dose of the $\mathrm{VIP}_{1}$ receptor agonist. The fourth group received an i.v. injection of the $\mathrm{VIP}_{1}$ receptor antagonist immediately followed by an i.v. injection of the $\mathrm{VIP}_{2}$ receptor agonist.

In a fourth series of experiments we investigated the interaction between NO and VIP on the transit after the laparotomy plus mechanical stimulation. Therefore the rats were randomly divided in four groups. The first group served as control group and received an i.v. injection of $0.9 \%$ sodium chloride $1 \mathrm{~min}$ before the laparotomy plus mechanical stimulation. The second group received an i.v. injection of the $\mathrm{VIP}_{1}$ receptor antagonist $\left(5 \mu \mathrm{g} \mathrm{kg}^{-1}\right) 1 \mathrm{~min}$ before the laparotomy plus mechanical stimulation. The third group received an i.v. injection of L-nitroarginine $\left(5 \mathrm{mg} \mathrm{kg}^{-1}\right)$, the NO synthase inhibitor, $1 \mathrm{~min}$ before the laparotomy plus mechanical stimulation. The fourth group received an i.v. injection of the $\operatorname{VIP}_{1}$ receptor antagonist $\left(5 \mu \mathrm{g} \mathrm{kg}^{-1}\right)$ immediately followed by an i.v. injection of L-nitroarginine $\left(5 \mathrm{mg} \mathrm{kg}{ }^{-1}\right) 1 \mathrm{~min}$ before the laparotomy plus mechanical stimulation.

Finally, we investigated the effect of the combination of the VIP $_{1}$ receptor antagonist and L-nitroarginine on the transit after skin incision. We previously demonstrated that the transit after skin incision was comparable to the transit in untreated rats (De Winter et al., 1997). Therefore, we investigated the effect of the combination therapy on the transit after skin incision. The rats were divided in two groups. The first group served as control group and received an i.v. injection of $0.9 \%$ sodium chloride $1 \mathrm{~min}$ before the skin incision. The second group received an i.v. injection of the $\mathrm{VIP}_{1}$ receptor antagonist $\left(5 \mu \mathrm{g} \mathrm{kg}^{-1}\right)$ immediately followed by an i.v. injection of $\mathrm{L}-$ nitroarginine $\left(5 \mathrm{mg} \mathrm{kg}^{-1}\right) 1 \mathrm{~min}$ before the skin incision.

\section{Drugs used}

The following drugs were used: diethyl ether (Merck, Darmstadt, Germany), Evans blue, $\mathrm{N}^{\omega}$-nitro-L-arginine (Sigma, St. Louis, U.S.A.), sodium chloride $0.9 \%$ (Plurule $^{\circledR}$, Baxter, Lessines, Belgium). Ac-Hisl,D-Phe ${ }^{2}, \mathrm{~K}^{15}, \mathrm{R}^{16}$, VIP(37), $\mathrm{GRF}(8-27)-\mathrm{NH}_{2}$, the $\mathrm{VIP}_{1}$ receptor antagonist; $\mathrm{K}^{15}, \mathrm{R}^{16}$, $\operatorname{VIP}(1-7), \operatorname{GRF}(8-27)-\mathrm{NH}_{2}$, the $\mathrm{VIP}_{1}$ receptor agonist and RO 25-1553, the $\mathrm{VIP}_{2}$ receptor agonist were synthesised by the Department of Biochemistry and Nutrition, Medical School, Université Libre de Bruxelles, Brussels, Belgium. All products were dissolved in $0.9 \%$ sodium chloride.

\section{Presentation of results and statistical analysis}

The total length of the small intestine was not statistically different between the groups (data not shown). Therefore, results are expressed as $\mathrm{cm}$ migration of Evans blue and the measurements were made from the pylorus to the most distal point of migration of Evans blue. Group differences were 
assessed by simple factorial analysis of variance (ANOVA) and two-way analysis of variance. When the two way analysis of variance showed a signficant interaction between the factors, a one way analysis of variance followed by a Student-NewmanKeuls test for multiple comparisons was performed. A one way analysis of variance followed by a Dunnett test was used to study the dose-dependent effect of the $\mathrm{VIP}_{1}$ receptor antagonist. When only two groups were involved an unpaired Student's $t$-test was used. Values are shown as mean \pm s.e.mean for $n$ indicating the number of rats used. $P$ values $\leqslant 0.05$ were considered to be significant. All data were analysed with the SPSS for Windows software (SPSS Inc., Chicago, IL, U.S.A.).

\section{Results}

Effect of different doses of the $V I P_{1}$ receptor antagonist

To investigate the optimal dose of the $\mathrm{VIP}_{1}$ receptor antagonist, we treated the rats with different doses of the VIP VI $_{1}$ receptor antagonist. The transit after the laparotomy plus mechanical stimulation in control rats was $17.4 \pm 1.7 \mathrm{~cm}(n=6$; Figure 1) and was not significantly altered by a dose of $3 \mu \mathrm{g} \mathrm{kg}^{-1} \mathrm{VIP}_{1}$ receptor antagonist $(20.4 \pm 1.6 \mathrm{~cm} ; n=6$; Figure 1). However, the transit was significantly increased from $17.4 \pm 1.7 \mathrm{~cm}$ in control rats to $25.1 \pm 2.0 \mathrm{~cm}$ in rats treated with a dose of $5 \mu \mathrm{g} \mathrm{kg}^{-1}$ and to $24.8 \pm 2.6 \mathrm{~cm}$ in rats treated with a dose of $10 \mu \mathrm{g} \mathrm{kg}^{-1}$ of the $\mathrm{VIP}_{1}$ receptor antagonist $(n=6$; Figure 1$)$. As the $\mathrm{VIP}_{1}$ receptor antagonist reached a maximal increase in the transit after a dose of $5 \mu \mathrm{g} \mathrm{kg}^{-1}$, we treated the rats with a dose of $5 \mu \mathrm{g} \mathrm{kg}^{-1}$ in all further experiments.

\section{Effect of VIP ${ }_{1}$ receptor agonist and antagonist on intestinal transit}

In control rats, treated with $0.9 \%$ sodium chloride, the transit after skin incision was $55.5 \pm 3.2 \mathrm{~cm}(n=9$; Figure 2$)$. We previously showed that the transit after skin incision was comparable to the transit in untreated rats (De Winter et al., 1997). The laparotomy significantly delayed the transit to

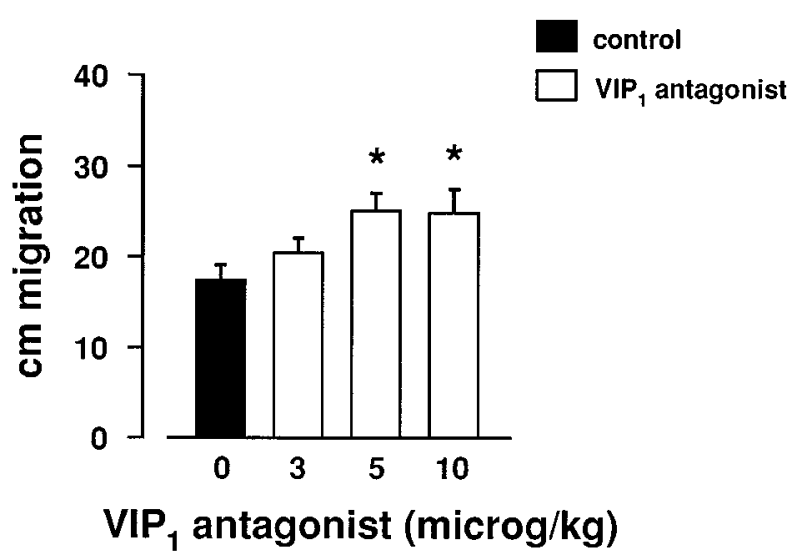

Figure 1 Effect of laparotomy plus mechanical stimulation of the small intestine and caecum on the intestinal transit in control rats (solid bars, $n=6$ ) and in rats treated with $\mathrm{VIP}_{1}$ receptor antagonist $3 \mu \mathrm{g} \mathrm{kg}^{-1}, 5 \mu \mathrm{g} \mathrm{kg}^{-1}$ and $10 \mu \mathrm{g} \mathrm{kg}^{-1}$ (open bars, $n=6$ ). Results are expressed as $\mathrm{cm}$ migration of Evans blue and shown as mean \pm s.e.mean. ${ }^{*}, P \leqslant 0.05$, significantly different from the transit in control rats; one way analysis of variance followed by the Dunnett test for multiple comparisons.
$43.1 \pm 2.6 \mathrm{~cm}(n=9 ;$ Figure 2$)$. This inhibition was even more pronounced when the laparotomy was followed by a mechanical stimulation of the gut: the transit was $17.8 \pm 1.8 \mathrm{~cm}$ $(n=9$; Figure 2).

Treatment of the rats with the $\mathrm{VIP}_{1}$ receptor antagonist $\left(5 \mu \mathrm{g} \mathrm{kg}^{-1}\right)$, the $\mathrm{VIP}_{1}$ receptor agonist $\left(5 \mu \mathrm{g} \mathrm{kg}^{-1}\right)$ or the combination of the $\mathrm{VIP}_{1}$ receptor antagonist and agonist had no effect on the transit after skin incision or laparotomy $(n=9$; Figure 2). However, the $\mathrm{VIP}_{1}$ receptor antagonist significantly increased the transit after the laparotomy plus mechanical stimulation from $17.8 \pm 1.8 \mathrm{~cm}$ in control rats to $25.8 \pm 2.3 \mathrm{~cm}$ in rats treated with the $\mathrm{VIP}_{1}$ receptor antagonist $(n=9$; Figure $2)$. On the contrary, the $\operatorname{VIP}_{1}$ receptor agonist caused a small, but significant decrease in the transit after laparotomy plus mechanical stimulation from $17.8 \pm 1.8 \mathrm{~cm}$ in control rats to $13.3 \pm 2.1 \mathrm{~cm}$ in rats treated with the $\mathrm{VIP}_{1}$ receptor agonist $\left(n=9\right.$; Figure 2). The effect of the $\mathrm{VIP}_{1}$ receptor antagonist and the effect of the $\mathrm{VIP}_{1}$ receptor agonist were abolished when both treatments were combined: the transit after the laparotomy plus mechanical stimulation was $17.7 \pm 2.5 \mathrm{~cm}$ $(n=9)$ and thus comparable to the transit after laparotomy plus mechanical stimulation in control rats (Figure 2).

However, even after administration of the $\mathrm{VIP}_{1}$ receptor antagonist, the transit after laparotomy plus mechanical stimulation was still significantly different from the transit after skin incision or laparotomy in all treatment groups indicating that the $\mathrm{VIP}_{1}$ receptor antagonist was not able to completely reverse the additional inhibition induced by mechanical stimulation of the gut.

\section{Effect of the $\mathrm{VIP}_{2}$ receptor agonist on intestinal transit}

The $\mathrm{VIP}_{1}$ receptor antagonist $\left(5 \mu \mathrm{g} \mathrm{kg}^{-1}\right)$, the $\mathrm{VIP}_{2}$ receptor agonist $\left(5 \mu \mathrm{g} \mathrm{kg}^{-1}\right)$ or the combination of the $\mathrm{VIP}_{1}$ receptor antagonist and the $\mathrm{VIP}_{2}$ receptor agonist had no effect on the transit after skin incision or laparotomy compared to control rats $(n=9$; Figure 3$)$. The $\operatorname{VIP}_{1}$ receptor antagonist signifi-

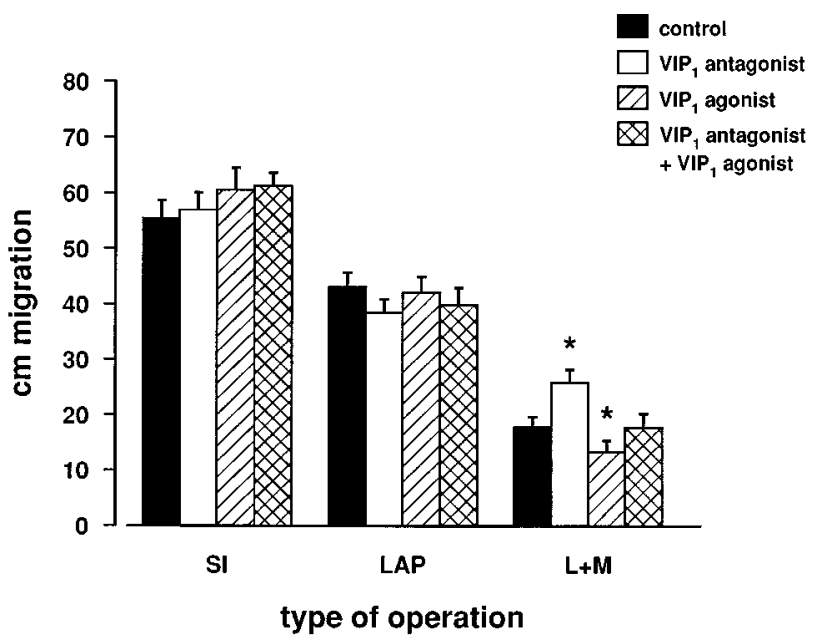

Figure 2 Effect of skin incision (SI), laparotomy (LAP) or laparotomy plus mechanical stimulation of the small intestine and caecum $(\mathrm{L}+\mathrm{M})$ on the intestinal transit in control rats (solid bars, $n=9)$ and in rats treated with $\mathrm{VIP}_{1}$ receptor antagonist $5 \mu \mathrm{g} \mathrm{kg}^{-1}$ (open bars, $n=9$ ) or with $\mathrm{VIP}_{1}$ receptor agonist $5 \mu \mathrm{g} \mathrm{kg}^{-1}$ (hatched bars, $n=9$ ) or with the combination of $\mathrm{VIP}_{1}$ receptor antagonist and VIP $_{1}$ receptor agonist (cross-hatched bars, $n=9$ ). Results are expressed as $\mathrm{cm}$ migration of Evans blue and shown as mean \pm s.e.mean. ${ }^{*}, P \leqslant 0.05$, significant effect of the two factors $\left(\mathrm{VIP}_{1}\right.$ receptor antagonist, $\mathrm{VIP}_{1}$ receptor agonist) in two way analysis of variance. 


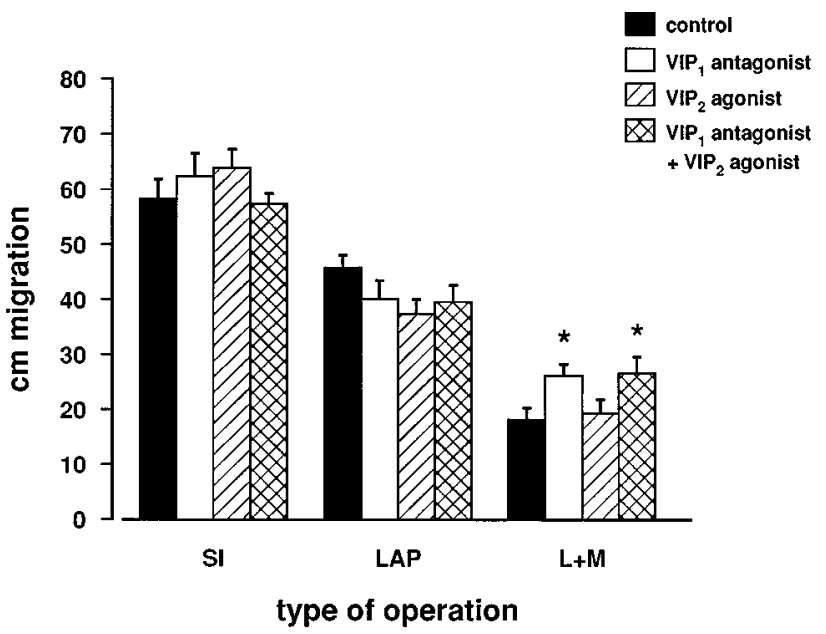

Figure 3 Effect of skin incision (SI), laparotomy (LAP) or laparotomy plus mechanical stimulation of the small intestine and caecum $(\mathrm{L}+\mathrm{M})$ on the intestinal transit in control rats (solid bars, $n=9)$ and in rats treated with $\mathrm{VIP}_{1}$ receptor antagonist $5 \mu \mathrm{g} \mathrm{kg}^{-1}$ (open bars, $n=9$ ) or with $\mathrm{VIP}_{2}$ receptor agonist $5 \mu \mathrm{g} \mathrm{kg}^{-1}$ (hatched bars, $n=9$ ) or with the combination of $\mathrm{VIP}_{1}$ receptor antagonist and the $\mathrm{VIP}_{2}$ receptor agonist (cross-hatched bars, $n=9$ ). Results are expressed as $\mathrm{cm}$ migration of Evans blue and shown as mean \pm s.e.mean. *, $P \leqslant 0.05$, significant effect of one factor $\left(\mathrm{VIP}_{1}\right.$ receptor antagonist) in two way analysis of variance.

cantly increased the transit after the laparotomy plus mechanical stimulation from $18.2 \pm 2.1 \mathrm{~cm}$ in control rats to $26.2 \pm 2.0 \mathrm{~cm}$ in rats treated with the $\mathrm{VIP}_{1}$ receptor antagonist $(n=9$; Figure 3$)$. In contrast to the $\mathrm{VIP}_{1}$ receptor agonist, the $\mathrm{VIP}_{2}$ receptor agonist had no effect on the transit after the laparotomy plus mechanical stimulation: the transit was $19.3 \pm 2.5 \mathrm{~cm}(n=9$; Figure 3$)$. The $\mathrm{VIP}_{2}$ receptor agonist was also not able to counteract the effect of the $\mathrm{VIP}_{1}$ receptor antagonist on the transit after laparotomy plus mechanical stimulation: the transit after combined treatment was $26.6 \pm 3.0 \mathrm{~cm}(n=9)$ which was comparable to the transit after the VIP $_{1}$ antagonist alone (Figure 3).

The transit after the laparotomy plus mechanical stimulation was significantly different from the transit after skin incision or laparotomy in all treatment groups.

\section{Interaction between VIP and NO}

We investigated the effect of combined treatment with the VIP $_{1}$ receptor antagonist and L-nitroarginine on the transit after the laparotomy plus mechanical stimulation. The transit after the laparotomy plus mechanical stimulation in control rats was $16.6 \pm 1.8 \mathrm{~cm}$, which was significantly increased to $25.4 \pm 1.7 \mathrm{~cm}$ after treatment with the $\mathrm{VIP}_{1}$ receptor antagonist $(n=7$; Figure 4$)$. Treatment of rats with the NO synthase inhibitor L-nitroarginine increased the transit after laparotomy plus mechanical stimulation to $32.7 \pm 3.7 \mathrm{~cm}(n=7$; Figure 4$)$, which was significantly different from the transit after treatment with the $\mathrm{VIP}_{1}$ receptor antagonist. However, the combination of the $\mathrm{VIP}_{1}$ receptor antagonist and L-nitroarginine resulted in a transit of $18.4 \pm 1.5 \mathrm{~cm}$ which was comparable to the transit in control rats $(n=7$; Figure 4$)$.

Since both drugs, when administered together, lost their beneficial effect on the transit after the laparotomy plus mechanical stimulation, we investigated the effect of combined treatment on the transit after skin incision. We previously demonstrated that L-nitroarginine did not alter the transit after

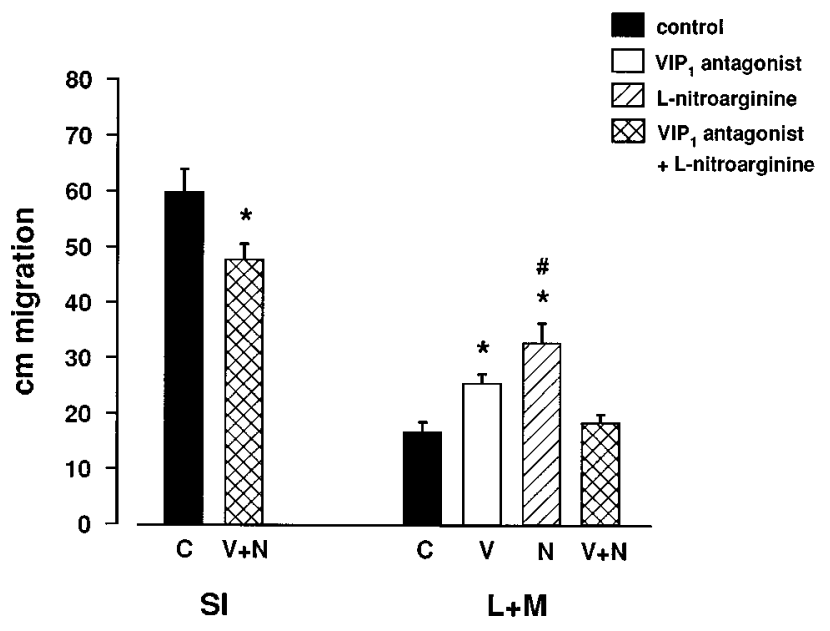

Figure 4 Effect of skin incision (SI) or laparotomy plus mechanical stimulation of the small intestine and caecum $(\mathrm{L}+\mathrm{M})$ on the intestinal transit in control rats $(\mathrm{C}$, solid bars, $n=7)$ and in rats treated with the $\mathrm{VIP}_{1}$ receptor antagonist $5 \mu \mathrm{g} \mathrm{kg}^{-1}$ (V, open bars, $n=7)$ or with L-nitroarginine $5 \mathrm{mg} \mathrm{kg}^{-1}(\mathrm{~N}$, hatched bars, $n=7)$ or with the combination of the $\mathrm{VIP}_{1}$ receptor antagonist and $\mathrm{L}$ nitroarginine $(\mathrm{V}+\mathrm{N}$, cross-hatched bars, $n=6-7)$. Results are expressed as $\mathrm{cm}$ migration of Evans blue and shown as mean \pm s.e.mean. *,$P \leqslant 0.05$, significantly different from the transit in control rats with the same operation; $\#, P \leqslant 0.05$, significantly different from other treatment groups after the laparotomy plus mechanical stimulation; unpaired Student's $t$-test (skin incision) and one way analysis of variance followed by the Student Newman Keuls test for multiple comparisons (laparotomy plus mechanical stimulation).

skin incision (De Winter et al., 1997) and in the present study we showed that also the VIP $_{1}$ receptor antagonist had no effect on the transit after skin incision. However, the combination of L-nitroarginine and the VIP $_{1}$ receptor antagonist significantly decreased the transit after skin incision from $59.8 \pm 4.1 \mathrm{~cm}$ in control rats to $47.8 \pm 2.9 \mathrm{~cm}$ in rats treated with the combination ( $n=6-7$; Figure 4$)$.

\section{Discussion}

The enteric nervous system has different inhibitory neurotransmitters of which NO and VIP are believed to play an important role in the non-adrenergic non-cholinergic (NANC) relaxation (Goyal et al., 1980; Grider \& Rivier, 1990; Boeckxstaens et al., 1991; Furness et al., 1992). In the present study, we demonstrate that next to NO (De Winter et al., 1997) also VIP, acting on the $\mathrm{VIP}_{1}$ receptors, is involved in the pathogenesis of postoperative ileus. This is, to the best of our knowledge, the first report on the use of a selective VIP $\mathrm{VI}_{1}$ and $\mathrm{VIP}_{2}$ receptor agonist and a selective $\mathrm{VIP}_{1}$ receptor antagonist in vivo. In our rat model of postoperative ileus, we applied three different nociceptive stimuli - skin incision, laparotomy and laparotomy plus mechanical stimulation of the gut - resulting in different degrees of inhibition of the gastrointestinal transit. Skin incision did not affect the gastrointestinal transit, whereas the transit was significantly delayed by the laparotomy. Mechanical stimulation of the small intestine and caecum resulted in an additonal inhibition of the gastrointestinal transit. Similar results were previously obtained by Bueno et al. (1978).

Recently the $\mathrm{VIP}_{1}$ and $\mathrm{VIP}_{2}$ receptor were cloned and it was shown that both receptors had a different distribution in the rat suggesting the possibility of differential effects (Usdin et al., 1994; Shuttleworth \& Keef, 1995). Using the selective VIP $_{1}$ 
receptor antagonist Ac-Hisl,D-Phe ${ }^{2}, \mathrm{~K}^{15}, \mathrm{R}^{16}$, VIP(3-7), GRF(8-27)- $\mathrm{NH}_{2}$ (Gourlet et al., 1997a), the selective VIP receptor agonist $\mathrm{K}^{15}, \mathrm{R}^{16}, \operatorname{VIP}(1-7), \quad \mathrm{GRF}(8-27)-\mathrm{NH}_{2}$ (Gourlet et al., 1997b) and the selective $\mathrm{VIP}_{2}$ receptor agonist RO 25-1553 (Gourlet et al., 1997c), we demonstrated the involvement of $\mathrm{VIP}_{1}$ receptors in the pathogenesis of postoperative ileus in rats. However, the $\mathrm{VIP}_{1}$ receptor antagonist, the $\mathrm{VIP}_{1}$ receptor agonist and the $\mathrm{VIP}_{2}$ receptor agonist had no effect on the transit after skin incision. Also Bojö et al. (1994) showed that VIP antiserum had no influence on basal gastric motility in the rat. Nevertheless, our findings support a role for the $\mathrm{VIP}_{1}$ receptor in the regulation of the intestinal transit after mechanical stimulation of the gut since the $\mathrm{VIP}_{1}$ receptor agonist significantly enhanced the inhibition of the transit induced by mechanical stimulation of the gut, whereas the $\mathrm{VIP}_{1}$ receptor antagonist significantly improved the transit after the laparotomy plus mechanical stimulation. The effect of the $\mathrm{VIP}_{1}$ receptor agonist and antagonist on the transit after the laparotomy plus mechanical stimulation disappeared when both treatments were combined. The $\mathrm{VIP}_{2}$ receptor agonist had no effect on the transit after the laparotomy plus mechanical stimulation and was also not able to alter the effect of the VIP $_{1}$ receptor antagonist on the transit after the laparotomy plus mechanical stimulation, confirming the selectivity of the tested compounds. Previously, Espat et al. (1995) reported a beneficial effect of a non-selective VIP receptor antagonist on postoperative small bowel transit and a faster return of the migrating motor complex. In dogs with small bowel obstruction an increased VIP release was demonstrated in the portal and systemic circulation (Basson et al., 1989). Together, these results suggest an increased release of VIP, acting on the VIP receptors, after mechanical stimulation of the gut resulting in an inhibition of the gastrointestinal transit.

However, the VIP $_{1}$ receptor antagonist was not able to completely reverse the additional inhibition of the transit induced by mechanical stimulation of the gut. This may result from incomplete blockade of VIP receptors or from the involvement of other inhibitory neurotransmitters. Previously, we showed that the NO synthase inhibitor, L-nitroarginine, completely reversed the additional inhibition induced by mechanical stimulation of the gut (De Winter et al., 1997). This effect of L-nitroarginine on the transit after laparotomy plus mechanical stimulation was more pronounced than the effect of the $\mathrm{VIP}_{1}$ receptor antagonist. NO and VIP are both important inhibitory neurotransmitters of the enteric nervous system (Goyal et al., 1980; Grider \& Rivier, 1990; Boeckxstaens et al., 1991; Furness et al., 1992; Goyal \& Hirano, 1996). As there are several hypotheses about the interaction between VIP and NO, depending on the species and the region under study (for review see Daniel et al., 1994), we investigated the interaction between NO and VIP in the pathogenesis of postoperative ileus. Surprisingly, the beneficial effects of the $\mathrm{VIP}_{1}$ receptor antagonist and L-nitroarginine disappeared when both were administered simultaneously. Since both NO and VIP mediate the descending inhibition of the peristaltic reflex (Furness et al., 1992; Grider, 1993; Goyal \& Hirano, 1996), it is possible that blockade of both these inhibitory neurotransmitters results in decreased intestinal propulsion. However, blockade of one inhibitory neurotransmitter may have a beneficial effect on the transit after the laparotomy plus mechanical stimulation since the other inhibitory neurotransmitter sustains the descending inhibition of the peristaltic reflex. As such, blockade of both inhibitory neurotransmitters may overcome the observed beneficial effect of both blockers administered alone and prevent appropriate intestinal propulsion. Alternatively, there may be a chemical interaction in vivo between the $\mathrm{VIP}_{1}$ receptor antagonist and L-nitroarginine or a pharmacological synergism between NO and VIP.

To support our hypothesis we investigated the effect of blockade of the inhibitory neurotransmitters NO and VIP on the transit after skin incision. The transit after skin incision was not affected by NO blockade, as demonstrated previously (De Winter et al., 1997), nor by the $\mathrm{VIP}_{1}$ receptor antagonist as shown in the present study. However, blockade of both NO and VIP resulted in a decreased transit after skin incision indicating that at least one of these inhibitory neurotransmitters is needed to enable normal gastrointestinal transit. As we previously demonstrated that the transit after skin incision is comparable to the transit in normal conditions (De Winter et al., 1997), these results suggest that blockade of both inhibitory neurotransmitters inhibits normal intestinal transit.

In summary, previously we demonstrated the involvement of $\mathrm{NO}$ in the additional inhibition induced by mechanical stimulation of the gut. In this study we showed that next to NO also VIP, acting on the $\mathrm{VIP}_{1}$ receptor, contributes to the inhibition of the transit induced by mechanical stimulation of the gut, suggesting the involvement of NO and VIP in the pathogenesis of postoperative ileus. However, the combination of the $\mathrm{VIP}_{1}$ receptor antagonist and the NO synthase inhibitor abolished the beneficial effect of each inhibitor alone which suggests the need for one of the inhibitory neurotransmitters to enable normal gastrointestinal transit.

Benedicte De Winter is a research assistant of the Fund for Scientific Research-Flanders (F.W.O.), Belgium. This work was supported by the F.W.O.-Flanders, Belgium (Grant nr. G.0220.96) and by the Interuniversity Poles of Attraction Progam - Belgian State, Prime Minister's Office - Federal Office for Scientific, Technical and Cultural affairs. The authors wish to thank Mrs L. Van de Noort for typing the manuscript.

\section{References}

ABRAHAMSSON, H., GLISE, H. \& GLISE, K. (1979). Reflex suppression of gastric motility during laparotomy and gastroduodenal nociceptive stimulation. Scand. J. Gastroenterol., 14, $101-106$

BASSON, M.D., FIELDING, L.P., BILCHIK, A.J., ZUCKER, K.A., BALLANTYNE, G.H., SUSSMAN, J., ADRIAN, T.E. \& MODLIN, I.M. (1989). Does vasoactive intestinal polypeptide mediate the pathophysiology of bowel obstruction? Am. J. Surg., 157, 109115.

BoecKXSTAENS, G.E., PELCKMANS, P.A., BOGERS, J.J., BUlt, H., DE MAN, J.G., OOSTERBOSCH, L., HERMAN, A.G. \& VAN MAERCKE, Y.M. (1991). Release of nitric oxide upon stimulation of nonadrenergic noncholinergic nerves in the rat gastric fundus. J Pharmacol. Exp. Ther., 256, $441-447$.

BOJO, L., CASSUTO, J., NEllgARD, P. \& JONSSON, A. (1994). Adrenergic, cholinergic and VIP-ergic influence on gastric phasic motility in the rat. Acta Physiol. Scand., 150, 67-73.

BUENO, L., FERRE, J.P. \& RUCKEBUSCH, Y. (1978). Effects of anesthesia and surgical procedures on intestinal myoelectric activity in rats. Am. J. Dig. Dis., 23, 690-695.

COSTA, M., FURNESS, J.B., POMPOLO, S., BROOKES, S.J.H., BORNSTEIN, J.C., BREDT, D.S. \& SNYDER, S.H. (1992). Projections and chemical coding of neurons with immunoreactivity for nitric oxide synthase in the guinea-pig small intestine. Neurosci. Lett., 148, $121-125$. 
DANIEL, E.E., FOX-THRELKELD, J.E.T., MAO, Y.K., WANG, Y.F., CAYABYAB, F., JIMINEZ, M., VERGARA, P. \& MEMEH, C. (1994). Interactions of VIP (vasoactive intestinal polypeptide) and nitric oxide (NO) in mediating intestinal inhibition. Biomed. Res., 15, $69-77$.

DE WINTER, B.Y., BOECKXSTAENS, G.E., DE MAN, J.G., MOREELS, T.G., HERMAN, A.G. \& PELCKMANS, P.A. (1997). Effect of adrenergic and nitrergic blockade on experimental ileus in rats. Br. J. Pharmacol., 120, $464-468$.

DUBOIS, A., WEISE, V.K. \& KOPIN, I.J. (1973). Postoperative ileus in the rat: physiopathology, etiology and treatment. Ann. Surg., 178, $781-786$.

EKBLAD, E., MULDER, H., UDDMAN, R. \& SUNDLER, F. (1994). NOS-containing neurons in the rat gut and coeliac ganglia. Neuropharmacology, 33, $1323-1331$.

ESPAT, N.J., CHENG, G., KELLEY, M.C., VOGEL, S.B., SNINSKY, C.A. \& HOCKING, M.P. (1995). Vasoactive intestinal peptide and substance P receptor antagonists improve postoperative ileus. $J$. Surg. Res., 58, 719-723.

FURNESS, J.B., BORNSTEIN, J.C., MURPHY, R. \& POMPOLO, S. (1992). Roles of peptides in transmission in the enteric nervous system. Trends Neurosci., 15, 66-71.

FURNESS, J.B. \& COSTA, M. (1974). Adynamic ileus, its pathogenesis and treatment. Med. Biol., 52, $82-89$.

GOURLET, P., DE NEEF, P., CNUDDE, J., WAELBROECK, M. \& ROBBERECHT, P. (1997a). In vitro properties of a high affinity selective antagonist of the $\mathrm{VIP}_{1}$ receptor. Peptides, 18, 15551560 .

GOURLET, P., VANDERMEERS, A., VERTONGEN, P., RATHE, J., DE NEEF, P., CNUDDE, J., WAELBROECK, M. \& ROBBERECHT, P. (1997b). Development of high affinity selective VIP $_{1}$ receptor agonists. Peptides, 18, $1539-1545$.

GOURLET, P., VERTONGEN, P., VANDERMEERS, A., VANDERMEERS-PIRET, M.C., RATHE, J., DE NEEF, P., WAELBROECK, M. \& ROBBERECHT, P. (1997c). The long-acting vasoactive intestinal polypeptide agonist RO 25-1553 is highly selective of the $\mathrm{VIP}_{2}$ receptor subclass. Peptides, 18, $403-408$.
GOYAL, R.K. \& HIRANO, I. (1996). The enteric nervous system. New Engl. J. Med., 334, 1106-1115.

GOYAL, R.K., RATTAN, S. \& SAID, S.I. (1980). VIP as a possible neurotransmitter of non-cholinergic non-adrenergic inhibitory neurones. Nature, 288, $378-380$.

GRIDER, J.R. (1993). Interplay of VIP and nitric oxide in regulation of the descending relaxation phase of peristalsis. Am. J. Physiol., 264, G334-G340.

GRIDER, J.R. \& RIVIER, J.R. (1990). Vasoactive intestinal peptide (VIP) as transmitter of inhibitory motor neurons of the gut: evidence from the use of selective VIP antagonists and VIP antiserum. J. Pharmacol. Exp. Ther., 253, 738-742.

HOLZER, P., LIPPE, I.T. \& HOLZER-PETSCHE, U. (1986). Inhibition of gastrointestinal transit due to surgical trauma or peritoneal irritation is reduced in capsaicin-treated rats. Gastroenterology, 91, 360-363.

LIVINGSTON, E.H. \& PASSARO, E.P. (1990). Postoperative ileus. Dig. Dis. Sci., 35, $121-132$.

LYNN, R.B., SANKEY, S.L., CHAKDER, S. \& RATTAN, S. (1995) Colocalization of NADPH-diaphorase staining and VIP immunoreactivity in neurons in opossum internal anal sphincter. Dig. Dis. Sci., 40, 781-791.

SHUTTLEWORTH, C.W.R. \& KEEF, K.D. (1995). Roles of peptides in enteric neuromuscular transmission. Regulatory Peptides, 56, $101-120$.

TANILA, H., KAUPPILA, T. \& TAIRA, T. (1993). Inhibition of intestinal motility and reversal of postlaparotomy ileus by selective $\alpha_{2}$-adrenergic drugs in the rat. Gastroenterology, 104, $819-824$.

USDIN, T.B., BONNER, T.I. \& MEZEY, E. (1994). Two receptors for vasoactive intestinal polypeptide with similar specificity and complementary distributions. Endocrinology, 135, 2662-2680.

(Received April 2, 1998 Accepted April 21, 1998 